O'Driscoll, C. (2017) Knowing and forgetting the Easter 1916 Rising. Australian Journal of Politics and History, 63(3), pp. 419-429. (doi:10.1111/ajph.12371)

There may be differences between this version and the published version. You are advised to consult the publisher's version if you wish to cite from it.

This is the peer-reviewed version of the following article: O'Driscoll, C. (2017) Knowing and forgetting the Easter 1916 Rising. Australian Journal of Politics and History, 63(3), pp. 419-429, which has been published in final form at 10.1111/ajph.12371. This article may be used for non-commercial purposes in accordance with Wiley Terms and Conditions for Self-Archiving.

http://eprints.gla.ac.uk/149937/

Deposited on: 17 October 2017

Enlighten - Research publications by members of the University of Glasgow http://eprints.gla.ac.uk 


\section{Knowing and Forgetting the Easter 1916 Rising}

Cian O’Driscoll

University of Glasgow

cian.odriscoll@glasgow.ac.uk

\section{Introduction}

"Life springs from death; and from the graves of patriot men and women spring living nations."

The Easter Rising took place on Easter Monday, the 24th April, 1916. Focused primarily on a set of strategic locations in the heart of Dublin, it was directed by the Irish Republican Brotherhood (IRB) and carried out by a militant force of no more than 1,600 men and women. The Rising began when rebels seized several buildings in Dublin city-centre, including the General Post Office (GPO), from where Patrick Pearse later that day proclaimed the establishment of the Irish Republic. The British government, busy in Flanders, was caught cold. Once it became seized of the situation, the insurrection was swiftly crushed. Fighting lasted less than a week. Nearly 500 people were killed, 2,000 were wounded; the bulk of these casualties were civilians. Initially, the public response to the Rising was hostile: it provoked ire from the people of Dublin, many of whom had friends or family fighting on the Western Front. Viewed in operational terms, then, the Rising was a dismal failure. Yet this was all part of the plan. Anticipating military defeat, the leaders of the Rising placed their faith in the idea that their "blood sacrifice" would prefigure a national revolution that would sweep all before it and lead Ireland to its freedom. ${ }^{2}$ The Crown's hasty decision to execute the leaders of the Rising-Patrick Pearse, Thomas Clarke, Thomas

\footnotetext{
${ }^{1}$ Patrick Pearse, Graveside Panegyric for O’Donovan Rossa at Glasnevin Cemetery, 1 August 1915. Available at: http://www.easter1916.net/oration.htm. 2 Sean Farrell Moran, "Patrick Pearse and the European Revolt against Reason", Journal of the History of Ideas Vol. 50, 4 (1989), p. 638.
} 
McDonagh, Joseph Plunkett, Edward Daly, Michael O'Hanrahan, Willie Pearse, Eamonn Ceantt, Michael Mallin, Sean Heuston, Con Colbert, Thomas Kent, Sean MacDiarmada, and James Connolly-vindicated this idea by turning popular sentiment in favour of the nationalist cause and ensuring that its slain leaders would be hailed as martyrs. Ireland now had "names that march with time". ${ }^{3}$

The details of the Easter 1916 Rising and its immediate aftermath have been pored over by historians for many years now. The purpose of this article is not to review them. Rather, in keeping with the theme of the symposium of which it is a part, its purpose is to inquire into the meaning of the Rising today, that is, on its centenary. What, then, if anything, can the events of 1916 tell us about the Ireland of 2016? And what can the Ireland of 2016 tell us about what happened in 1916? These marching orders oblige us to think about Ireland's relationship with this very specific and politically freighted moment in its past. This in turn raises further questions. A century on, to what degree does the 1916 Rising continue to shape Irish political life? What legacy has it bequeathed? And how might that legacy best be negotiated? The argument put forward in this article is that any serious effort to grapple with these questions must involve reflection on the nature of the sacrifice offered by Pearse and his colleagues. What is the proper way to understand the debt that modern Ireland owes to the fallen of 1916? And how, if at all, should or must that debt be honoured?4

This article is structured in a simple manner. It is arranged around the discussion of three different personages, each of whom boasts, not only a very different relation to the events of 1916 , but also a very different view on the sacrifice it represents. Section One will treat Bob Geldof, who is perhaps more famous for his charitable work than his own music, but who has also in recent months expressed controversial thoughts regarding the centenary commemoration of 1916. Section Two will look at the man whose poetry Geldof hails as an antidote to the poisonous nationalism the Easter Rising precipitated,

\footnotetext{
${ }^{3}$ Seumas O'Kelly, "The Seanachie Tells Another Story”, in Father Paddy Browne, ed., Aftermath of Easter Week (Dublin, 1917), p. 10.

4 This question encourages us to think about the relation between politics and historical memory. I will refrain in this paper from offering any substantive remarks on the scholarship in this area, but I direct the reader to the fine discussion of these matters in Jessica Auchter's paper in this special issue.
} 
W. B. Yeats. Section Three will turn to the writings of Walter McDonald, a Jesuit priest, one of the leading Catholic theologians of the early $20^{\text {th }}$ century, and a fascinating exponent of just war thinking. Finally, bringing all of this together, while also connecting to themes raised by Jessica Auchter, Jeremy Youde, and Matt McDonald elsewhere in this special issue, Section Four will turn to Jean Elshtain's idea of "knowing-forgetting" as a way of working through the relation between Ireland 1916 and Ireland 2016. Viewed as a whole, then, this article will seek to show both that the events of 1916 are still very much alive and kicking today, but that their meaning is for us, and not our forebears, to determine. If, in other words, a terrible beauty was indeed born in Easter 1916, as Yeats suggested, it is up to us what to do with it.

\section{How many murders have been sanctioned in its name}

Bob Geldof will be familiar to most readers. He was the singer and frontman of the Boomtown Rats, a new wave band from Ireland that achieved a certain level of critical and commercial success in the late 1970s and early 1980s. Geldof's subsequent involvement with, first, Band Aid and, then, Live Aid meant that he also became a household name in his own right, with his personal fame eclipsing that of his band. He has had a turbulent private life, suffering marital breakdown and multiple bereavements, and has at various times been the subject of noxious media interest. ${ }^{5}$ In 2016 Geldof campaigned against Brexit and for the Liberal Democrats in the Richmond Park by-election. It is, however, his controversial remarks on the 1916 Rising and its centenary commemoration that are of interest here.

The remarks in question were delivered in April 2016 as Geldof promoted a series of television documentaries he produced on the poetry of a man intimately connected to the events of 1916 , W. B. Yeats. ${ }^{6}$ Geldof was, it seems, moved to speak about the legacy of 1916 by his revulsion at what he perceived

\footnotetext{
${ }^{5}$ Scholars of International Relations may also recall that he was the target of one of Chris Brown's amusing broadsides. Chris Brown, "Bob Dylan, Live Aid, and the Politics of Popular Cosmopolitanism", in Practical Judgement in International Political Theory: Selected Essays (Abingdon, 2010): 250-63.

6 The documentaries in question are A Fanatic Heart (a two-part series first aired by RTE in April 2016) and Geldof on Yeats (aired by BBC4 in March 2016).
} 
as the reverence in which the men and women who partook in the Rising are currently held in Ireland. In particular, he expressed his disgust at the idea that these people have come to be viewed over time as martyrs, that is to say, as heroes who gave their lives in the service of a greater cause. "It's the original sin. So much rests on this myth. How many murders have been sanctioned in its name? $\mathrm{F}^{* * *}$ off! This messianic, delusional vertigo of self-sacrifice, the delirium of dying."7 He elaborated upon this complaint in a further remark to the effect that those who died partaking in the Rising were not martyrs, but were in fact narcissists with a death-wish. "They started writing these letters [to be read afterwards] which show clearly they knew, "The only thing that will come out of this is that we get shot, we get to be martyrs, that'll spur another generation."'8

The parallel Geldof was drawing between the participants in the 1916 Rising and contemporary suicide bombers was deliberate and intentional. There is no difference, he suggested, between the letter-writing 1916 leaders and "the guy who's just walked into Pakistan and blown up 73 people at a Christian carnival in Lahore?"9 Lest there be any misapprehension that he was arguing that both sets of actions were anything but abhorrent, he continued:

If you have been put upon and you have no voice, you want to try and advance it in life but you can't, you pick up a stone at some point and throw it. If there's an AK-47 or a bomb, even better. This is not to excuse the death cultists, who like everyone else you abhor. It's so dismaying. The application form to be a suicide bomber is so manipulative, it's so brilliant, the psychology of these $c^{* * * *}$ behind it. They're despicable. ${ }^{10}$

Though hardly taboo, remarks such as these about the 1916 generation are not common currency in Irish political discourse. ${ }^{11}$ While the Civil War elicited

\footnotetext{
${ }^{7}$ Cole Moreton, "'I have never in my life felt the world so fragile, so on the brink of something terrible': Bob Geldof on War, ISIS, and the Poet who Made Him Love Ireland Again", Mail on Sunday, 2 April 2016. Available at: http://www.dailymail.co.uk/home/event/article-3517398/Bob-Geldof-warISIS-poet-love-Ireland-again.html. Accessed: 3 December 2016.

${ }^{8}$ Moreton, "I have never in my life"'.

${ }^{9}$ Moreton, "I have never in my life"'.

10 Moreton, "I have never in my life"'.

11 I am referring here only to the Republic of Ireland.
} 
bitter disputes down the years, the 1916 Rising has seldom functioned as a hotbutton topic-at least not to the same degree. ${ }^{12}$ We will return to this point momentarily. In the meantime, suffice it to say that the comparison with the Islamic State is unprecedented, but there is nothing to suggest that Geldof's anger is not genuine. Rather, it reflects his apparent disgust at the idea that the violent and self-regarding actions of the 1916 revolutionaries (no less than those of today's Islamic State militants) contain within them an example for others to emulate-or, worse again, some sort of divine mandate for others to follow. Geldof is, it seems, of a mind to repudiate the discourse of sacrifice as evoked by Pearse and company on the one hand, and Abu Bakr al-Baghdadi on the other, as a dangerous and self-aggrandizing mythology.

It was, for Geldof, outrageous that the Irish government would wish to mark the 1916 Rising by throwing a gala event on its centenary. ${ }^{13}$ His misgivings reflected broader concerns that, in celebrating 1916 as its sacred origin, the Irish state-i.e., the Republic of Ireland-was whitewashing over the more sinister, violent (and Catholic-more on this later) aspects of the Rising. And while the centenary commemorations did not turn out to be the gaudy, jingoistic affair that Geldof dreaded, their mere occurrence belies the state's interest in presenting 1916 as a patrimony to be claimed.

The irony, which Geldof does not note, is that, even as the state seeks to attach itself to the legacy of 1916, its relation to the Rising is deeply ambiguous. The strain of violent nationalism generated by the Rising not only set in motion the train of events that would lead to the foundation of the Republic of Ireland, it also inspired a succession of militant movements that sought to overthrow that

\footnotetext{
12 The fact that no major protests or political unrest arose in response to the centenary commemorations attests to this.

13 Speaking of the fiftieth anniversary celebrations hosted in Dublin in 1966, Geldof complained: “The 1916 commemoration on O'Connell Street was like a bad North Korea-type military parade with emotionally overblown television coverage." Bernice Harrison, "Bob Geldof Busts His Baggage Allowance in a Poetry-Political Broadcast”, Irish Times, 1 April 2016. Available at: http://www.irishtimes.com/culture/tv-radio-web/television-bob-geldof-bustshis-baggage-allowance-in-a-poetry-political-broadcast-1.2594010. Accessed: 3 December 2016.
} 
same state. ${ }^{14}$ Accordingly, although the Easter Rising can fairly be presented as an event that everyone in Ireland is keen to celebrate, it nevertheless represents very different things to different people. And while it stands to reason that the state should seek to steal the clothes of its nationalist rivals by claiming the legacy of 1916 for itself, this comes at some cost. There is, one might venture, a certain amount of hypocrisy involved. When it comes to the symbols of nationhood, this is, of course, to be expected-few countries are immune from it. What is more interesting, perhaps, is the image we arrive at of Ireland's relationship to its own past. As captured in so many Sebastian Barry novels, Ireland appears to view its own history as though through a cracked mirror. ${ }^{15}$

\section{The revolution devours its own young}

W. B. Yeats is considered by many to be one of the greatest poets of the $20^{\text {th }}$ century. Born in 1865 to a Protestant, Anglo-Irish elite family, he proudly identified as an Irishman (rather than as an Englishman abroad). In keeping with this, his poetry, while often abstract and esoteric, evokes romantic themes and draws heavily on Irish folklore. Yeats' own romantic life was dominated by his hapless devotion to Maud Gonne, a tall and striking society woman who was passionately committed to the cause of Irish nationalism. ${ }^{16}$ Gonne married and had a family with Major John MacBride, a man whom Yeats detested, and who was executed in May 1916 for his role in the Rising. Yeats was also, of course, at one time a member of the IRB. He played no part in the Rising, however, and indeed distanced himself from it, except to treat it in verse, as well as in his work as a playwright. He was appointed to the Irish Senate in 1922, awarded the Nobel Prize for Literature in 1923, and died in 1939.

It is easy to think of Yeats as a passive observer of the Rising. Yet this would not be correct. There has, to be sure, been a tendency to attribute the Rising to men of action-men such as Pearse and MacBride. These men have

\footnotetext{
14 This of course on the basis that the state in question does not comprise the whole island of Ireland, but only 26 of the 32 counties.

15 Most notably: Sebastian Barry, A Long, Long Way London, 2005); The Secret Scripture (London: Faber and Faber, 2008).

${ }^{16}$ For a biography of Yeats: R. F. Foster, W. B. Yeats, A Life: Volumes I and II (Oxford, 1998-2003).
} 
latterly been venerated in some circles as brave, pious, and visionary figures, who were fighting, on the one hand, against the forces of imperialism and colonial oppression and, on the other, for the freedom of church and country. The outrage in response to Geldof's remarks expressed by Father Joe McVeigh, an influential republican priest, is instructive in this regard. "Does he regard all those who took a stand against imperialism as jihadists? Does he regard Nelson Mandela and the many others who gave their lives in the struggle against imperialism as jihadists?"17 Gelfof, he argued, had failed to see that the Rising was a "courageous act of defiance that was justified in the circumstances in which they lived."18

We will return to the substance of McVeigh's judgement in the next section. Prior to that, if we wish to properly understand Yeats' relation to the Rising, it is important to consider the reasons why McVeigh reacted so angrily to Geldof's utterances. McVeigh's intervention is representative of a strand of opinion in Ireland which views 1916 through Catholic lenses. This perspective depicts the Rising as a devout undertaking that was led by brave men and women, such as Pearse, who embodied Catholic values. There is much to commend this view. While it is true that none of the bishops in Ireland in 1916 supported the Rising, only seven of them condemned it. Support for the Rising was also quite common among junior clergy. ${ }^{19}$ More tellingly perhaps, the Rosary was recited regularly by those manning the barricades in the GPO, while the insurgents also sent papal count George Plunkett to Rome prior to the Rising in a bid to procure the blessing of Pope Benedict XV for their mission. Further, prominent Protestant participants in the Rising, Countess Markiewicz and Roger Casement chief among them, converted to Catholicism while under arms. For

17 Cathal Barry, "Bob Geldof's Remarks About 1916 Leaders "Outrageous”Priest”, The Irish Catholic, 7 April 2016. Available at:

http://www.irishcatholic.ie/article/bob-geldof's-remarks-about-1916-leaders'outrageous'---priest. Accessed: 4 December 2016.

18 Fr Joe McVeigh, "A Just War: Yes", The Irish Catholic. Available at: http://irishcatholic.ie/article/just-war-yes. Accessed: 9 December 2016.

${ }^{19}$ Claire Simpson, "Easter Rising: Catholic Church Played 'Key Role' in 1916", Irish Times, 31 March 2016. Available at:

http://www.irishnews.com/news/easterrising/2016/03/31/news/easterrising-catholic-church-played-key-role-in-1916-469357/. Accessed: 4 December 2016. 
those on the frontline this was, it seems, a fight for faith as much as for fatherland. ${ }^{20}$ In light of this, the concerns expressed by McVeigh (and others) that the Catholic element of the Rising has been airbrushed from history in the 2016 commemorations are understandable. ${ }^{21}$

There is, however, another side to the story. The focus on the leaders of the Rising and their spiritual and religious disposition diverts attention away from its deeper roots. These deeper roots lie in the generation of artists and activists of which Yeats was very much a part. R. F. Foster has explored this idea in his excellent 2014 monograph, Vivid Faces. ${ }^{22}$ Foster's argument is that the energy and inspiration behind the 1916 Rising came, not so much from Pearse and his comrades, as from the diverse and sometimes radical cohort of bohemians that enlivened the Dublin cultural scene in the decades prior to 1916. Foster counts poets, actors, writers, painters, pamphleteers, and playwrights among their number. In the main, these people were, it is fair to say, Yeats' kind of people-not Pearse's. Only a few were Catholic; fewer again staunchly so. Many were atheists. Some campaigned for women's suffrage, others advocated for animal's rights. This was, in other words, a heterogeneous assemblage of youthful, wilful, and creative free spirits, and it was their contribution to Irish cultural and political life that paved the way for the 1916 Rising. Viewed from this angle, the problem is not so much that the Catholic element of the Rising has not been sufficiently acknowledged, it is that Pearse and company acted in a

20 This is how Pearse viewed it. He considered himself equal part Catholic and nationalist, and understood the two categories to run together. Writing in late 1915, he argued that Irish nationalism was "like a divine religion, national freedom bears the marks of unity, of sanctity, of catholicity, of apostolic succession." Patrick Pearse, Ghosts (Dublin, 1915). Quoted in: Clive Christie, Race and Nation: A Reader (London, 1998), p. 108. Also see: Eamon McCann, "Role of Catholic Church in Easter Rising Should be Remembered", Irish Times, 9 April 2015. Available at: http://www.irishtimes.com/opinion/eamonn-mccannrole-of-catholic-church-in-easter-rising-should-be-remembered-1.2168941. Accessed: 4 December 2016.

${ }^{21}$ For a thoughtful discussion of this viewpoint: Michael Kelly, "Is Catholicism Being Scrubbed from Ireland's 'Easter Rising'?”, Crux, 21 April 2016. Available at: https://cruxnow.com/church/2016/04/21/is-catholicism-being-scrubbedfrom-irelands-easter-rising/. Accessed: 4 December 2016.

${ }^{22}$ R. F. Foster, Vivid Faces: The Revolutionary Generation in Ireland 1890-1923 (London, 2014). My gratitude to Karen Wright and Kelly Kollman for bringing this book to my attention. 
manner redolent of cuckoos: first they inserted themselves into a scene created by Foster's radicals, and then they edged them out. Thus, to borrow Jacques Mallet du Pan's turn of phrase, the revolution devoured its own young.

The place of Yeats in this story, then, tells us something, not only about the paternity battle over the Rising, but also about how its history has subsequently been written. Was the Rising the work of men and women like Pearse, MacBride, and Markiewicz, and was it fought so that Ireland might be a Catholic nation? Or was it the creation of the artists and radicals that, like Yeats, inhabited Dublin's bohemian fringe and struggled for a plurality of causes, few of which would have accorded with Catholic sensibilities? What is at stake in either case is the question of whose sacrifice 1916 stands for, and how we understand the legacy of the Rising for modern Ireland.

\section{The atmosphere is too full of passion, and will be for long}

"The atmosphere is too full of passion, and will be for long. Our successors will see more clearly; and will make, for all sides, allowances too generous for such as we have lived through these dreadful last years."23 So wrote Walter McDonald in 1919. The purpose of this remark is twofold. In the first instance, it rehearses the conventional historian's plea for perspective and for scholarly detachment. The implication in this case is that the events of 1916 were still too fresh in the memory, and the mood on the street too febrile, to pass any kind of meaningful judgement on them. Second, and slightly at odds with this, it stands as a warning against what might be termed "moral amnesia". ${ }^{24}$ Future generations, McDonald counsels, should not attempt to, nor be permitted to, forget the visceral horrors and the true awfulness of the events under discussion. To gain a clearer sense of the significance of these remarks it is, however, necessary, to first say a few words about McDonald himself, and the book in which they appeared.

23 Walter McDonald, Some Ethical Questions of Peace and War (Dublin, 1998 [1919]), xix.

${ }^{24}$ David Rieff, "The Cult of Memory: When History does More Harm Than Good", Guardian, 2 March 2016. Available at: https://www.theguardian.com/education/2016/mar/02/cult-of-memorywhen-history-does-more-harm-than-good. Accessed: 4 December 2016. 
McDonald occupies an interesting place in Irish history. He was born in Mooncoin, a small rural town in County Kilkenny, in 1854, to a farming family. This was a time of significant change in Ireland: the Great Potato Famine was still a recent memory for most people, and, while the Church retained its central position, the balance of Irish society was shifting toward an English-speaking, literate, and post-feudal culture. McDonald was ordained a priest in 1876, and thereafter took up an academic post at Saint Patrick's College, Maynooth, to which he would devote the rest of his days. Maynooth at that time was a very interesting place to be. It benefitted from generous financial support from the British government, which saw it as a conservative force in Irish life and a bulwark against revolutionary nationalism. It was also at that time, Tom Garvin writes, "the most important Catholic seminary in the English-speaking world."25 McDonald was a very influential person within this set-up. He founded the Irish Theological Quarterly in 1906, published several books, and developed a reputation as the leading Irish theologian of his day. While he enjoyed a certain degree of academic renown, and the pulpit this afforded him, it is important to remember that he also wrote as a Catholic priest, and thus with a pastoral role in mind. ${ }^{26}$ He died in 1920, not long after his finest work, Some Ethical Questions of Peace and War, first appeared in print.

As Garvin remarks, "This book is extraordinary in several ways." ${ }^{27}$ In the first instance, it was published at a crucial juncture in Irish history. It appeared on bookshelves in 1919, three years after the Rising and just as the Irish electorate, prompted by the introduction by the Crown of conscription to Ireland and its continued refusal to implement Home Rule, switched its support from the Irish Parliamentary Party to the altogether more revolutionary Sinn Fein. This, then, was the moment in which the worm turned and the Irish people, geed on by Catholic priests, ceased to acknowledge the legitimacy of British government

\footnotetext{
25 Tom Garvin, "Introduction”, in McDonald, Some Ethical Questions, xi-xii. 26 This, perhaps, ensured a very different style and approach from the one developed by the IR scholars writing at the time. For more on these figures, see David McCourt's contribution to this issue. On the idea of pastoral authority: Anthony F. Lang, Jr., "Narrative Authority", in Anthony F. Lang, Jr., Cian O'Driscoll, and John Williams, eds., Just War: Authority, Tradition, and Practice (Washington, DC, 2013), pp. 135-56.

27 Garvin, 'Introduction', xvi.
} 
in Ireland. McDonald did not, however, go along with popular sentiment. Rather, he argued that the state's legitimacy had long been accepted by the Catholic Church and that there was no need to alter this stance at this particular moment in time. Ireland, he added, had never been an independent nation, and while it surely possessed a right to local self-governance, it had no claim to its own state, nor to the use of force to achieve it. ${ }^{28}$ Provocatively perhaps, he also contended that what is good for the goose is sauce for the gander: if "Celtic Ireland" bore a right to independence on the basis of self-determination, it could hardly deny that same liberty to the "Saxon Ireland" of the Protestant minority. ${ }^{29}$ These considerations reflect the efforts of a Catholic patrician to stem the flow of populist nationalism and the Church's drift toward making common cause with it. Returning our minds-as promised-for a moment to issues raised in the previous discussion, McDonald's intention is evidently to refute any kind of idea that the Rising was, as Father Joe McVeigh put it, a courageous act of antiimperial defiance that was justified by the temper of the times and the circumstances in which Ireland found itself. ${ }^{30}$

Aside from all of this, McDonald's book is also quite a rare and valuable period piece. It offers a rich and thoughtful contemporary take on the ethics of the use of force in the context of the 1916 Rising. ${ }^{31}$ Schooled in Christian political theology, McDonald was well versed in the just war tradition and the ideal man to reflect upon its application to events in Ireland. His analysis is divided into two parts, the first devoted to "questions of peace", and the second to "questions of war". The latter is further divided into segments treating what we would today classify as jus ad bellum and jus in bello matters; jus post bellum

\footnotetext{
${ }^{28}$ McDonald, Some Ethical Questions, p. 15-16; 38; 95-96.

${ }^{29}$ McDonald, Some Ethical Questions, p. 70; 95-96; 105.

30 This underlines that there was no single Catholic view on the Rising. While some like McVeigh have expressed dismay that the Catholic element of the Rising has been airbrushed from the 2016 commemorations, others, like McDonald, argued at the time that it was anathema to Catholic teachings.

31 There are no works (at least in the English language) on just war ideas from this time. Most historians of the tradition overlook the early part of the $20^{\text {th }}$ century except to note developments in international law and the law of armed conflict. The story they convey is that just war thinking is reinvigorated in the 1940s and 1950s by figures such as G. E. M. Anscombe, John C. Ford, and Paul Ramsey. McDonald's book is thus a welcome surprise.
} 
concerns also feature, but they are largely confined to the margins. McDonald also offers some general remarks on the justice of war, and cites Catholic authorities (such as Francisco de Vitoria and Cardinal De Lugo) in support of his views. $^{32}$ A few points arise that will be of interest to just war scholars. McDonald, for instance, makes extensive use of the domestic analogy, reexamines the combatant/non-combatant distinction, reflects earnestly upon the legitimacy of reprisals, punitive war, and the rights and wrongs of annexation and of spheres of influence, and offers some remarks on the impact of new technologies (in this case, the submarine) upon the norms of war. ${ }^{33}$

While more than a few of McDonald's views appear old-fashioned or out of date, his analysis provides more than enough food for thought for anybody keen to resume scrutiny of the remarks by Bob Geldof, with which this article began. Two points rise to the fore. The first is that, in at least one respect, Geldof's comparison between Islamic State (IS) terrorists and the leaders of the 1916 Rising is less outrageous than McVeigh and others would lead one to believe. The issue turns on the principle of right authority, which stipulates both that the agent declaring war must be licenced by his/her community to do so, and that the community in question bears a right to levy war in the first instance. ${ }^{34}$ The approach adopted by the leaders of the Rising bears some basic similarities to that adopted by the leadership of Islamic State today and Al Qaeda in the late 1990's. In both cases there was some doubt, not necessarily over whether the agents carrying out the violence were authorised to do so by the community they claimed to represent, but over whether that community even in fact existed. On this point, McDonald clearly avers that such a community (i.e., the Irish nation) did not obviously exist at the time of the Rising-hence his reference to "Celtic" and "Saxon" Irelands. ${ }^{35}$

\footnotetext{
32 On the justice of war: p. 89-90. On Vitoria: p. 29. On De Lugo: p. 132.

33 McDonald, Some Ethical Questions, p. 98-99; 111-12; 113; 130-31; 102; and 121-27.

34 On proper authority: Anthony F. Lang, Jr., Cian O’Driscoll, and John Williams, eds., Just War: Tradition, Authority, Practice (Washington DC, 2013).

35 For a more detailed discussion of how retrospective 'memory building' exercises serve larger narratives of state-building Jelena Subotic's discussion of the 1914 Sarajevo assassination.
} 
McDonald's is, of course, merely one perspective-and a controversial one at that. It does, however, hint at a second, deeper point, which is that both the leaders of the Rising and the leaders of Al Qaeda conceived of the recourse to force in pre-figurative terms that lean heavily on the ideal of "martyrdom". Just as Osama Bin Laden and his accomplices sought to actualise the global Umma through shahid operations, so Pearse and his comrades sought to manifest the Irish nation through their blood-sacrifice. ${ }^{36}$ This is, one ventures, less shocking than it perhaps sounds. It is after all, to a greater or lesser extent, the modus operandi of most vanguard revolutionary movements. It also speaks on a more basic level to the recurrent trope in both Western and Islamic ethics of war that the act of taking up arms is an act of self-sacrificial service to one's community. ${ }^{37}$ Conversely, it says nothing about the different methods employed by today's terrorists and the men and women of the Rising. Accordingly, when Bob Geldof lumps together Islamic State suicide attacks carried out in crowded marketplaces with the actions of the insurrectionists in 1916, he obviates a meaningful distinction. There is, one hopes, no need to labour the point that targeting non-combatants in cold-blooded murder is a very different thing to taking up arms and picking a fight with a (much larger and better equipped) army.

\section{It is possible to both know and forget}

McDonald had something in common with Pearse. Both men were keen to ensure that the events of 1916 would not be forgotten. But their reasons for wanting this were opposed to one another. Pearse sought through the force of his actions to impose a fiduciary obligation upon subsequent generations of Irish men and women. The rebels who were killed in Dublin that week must not, he charged, have died in vain: their loss must be made to count for something. As such, he posited the Rising as an act of sacrifice that must be redeemed by those who came after him. McDonald's reasons for beseeching people not to forget the events of 1916 were cut from different cloth. He wanted people to remember,

36 On Al Qaeda: Gilles Kepel, Jihad: The Trail of Political Islam (London, 2009), p. 375-76.

37 This motif can be traced to major thinkers in both the jihad and just war traditions, and indeed is apparent in the sources McDonald cites (e.g., see p. 34). 
not the losses incurred by the rebels, but the violence of their ways and the suffering that their actions brought upon the ordinary people of Dublin. To forget these things would betoken, he supposed, a failure to learn from them. Just as bad, it would open up space for exactly the kind of naive romanticization that McDonald felt Pearse and his fellow revolutionaries should be denied. His call to remember was, then, in direct opposition to Pearse's. It was, one might say, a way of fighting historical memory with historical memory. ${ }^{38}$

The irony, then, is that, although they came from very different positions, both camps hold up the events of 1916 as a sacrifice to be honoured. In one case, the sacrifice of the rebels was vaunted as something that must be redeemed; in the other it was the suffering of the innocent that must be vindicated. In both instances, it seems to be assumed that honouring the past entails holding on it. There is, however, another interpreting the call to resist moral amnesia. It is contained in the idea of "knowing-forgetting" advanced by another just war scholar, the late Jean Bethke Elshtain. ${ }^{39}$ Elshtain's argument is that even as societies should not shy away from remembering and thinking about divisive historical events such as the 1916 Rising, they must relinquish the idea that the legacy of such events should be interpreted as some kind of sacred obligation or charge that cannot be easily shucked. ${ }^{40}$

She is very clear that this is not an invitation to forget or whitewash the violence of the past. "Remembrance of violent deeds goes forward in all its fullness and detail. A recounting of events serves as an ongoing judgement upon those most responsible." 41 At the same time, it is a counsel that one should not, so far as is possible, be dominated by the past that one inherits. We are obliged to remember the past, Elshtain contends, so that we do not become captive to it. "This is knowing-forgetting: recollecting the past, yes, but not being so wholly

\footnotetext{
${ }^{38}$ A related dynamic is examined by Jeremy Youde in his analysis of how the influenza pandemic of 1918-19 has been both remembered and forgotten.

${ }^{39}$ Jean Bethke Elshtain, "Just War and an Ethics of Responsibility" in Eric D. Patterson, ed., Ethics Beyond War's End (Washington DC, 2012), pp. 135-42. ${ }^{40}$ Elshtain, "Just War and an Ethics of Responsibility", p. 135.

41 Elshtain, "Just War and an Ethics of Responsibility", p. 135.
} 
defined by it that one's only option is either to be executioner or victim (in Albert Camus's memorable phrase), rather than an accountable human agent." 42

There is a classical precursor to this way of thinking. In ancient Greece, when a polis won a battle against one of its neighbours, it would raise a makeshift trophy to mark its victory. This both confirmed the outcome of the battle and signalled its conclusion. What is most interesting about this, however, is that it was forbidden to either construct the trophy from non-perishable materials or renew it. The idea behind this is that battles and victories were to be marked for posterity but not kept alive in perpetuity. As the trophy decomposed, so the communities in question should loosen their grip on the events it commemorates and acknowledge that they are now past. ${ }^{43}$ This is in stark contrast to modern commemorative practices which, similar to the position articulated (albeit with very different accents) by McDonald and Pearse, commands of us that we must remain seized of the events we seek to mark. ${ }^{44}$

This brings us back to Elshtain's formulation, which is not, she argues, a call for forgiving and forgetting. In the real world, she says, the notion that one can forgive and forget is an unhelpful truism. It is, however, "possible to both know and forget: to acknowledge the past without allowing it to dictate all of one's future, a release from the full weight and burden of the past." 45

\section{Conclusion}

By way of conclusion, it is worth noting how proximate 1916 is in the Irish imaginary. It is not a remote past, but rather an active one. It colours and informs aspects of Irish political and cultural life today. More than this, it still has the potential to spark controversy, and to set men like Bob Geldof and Father Joe McVeigh-whose paths would otherwise surely never have crossed-against one another. But what lesson are we-and here I am speaking of the Irish people-to take from it? What meaning does it hold for us today, a century after

\footnotetext{
42 Elshtain, "Just War and an Ethics of Responsibility", p. 135.

43 On Greek battlefield trophies: Cian O’Driscoll, "Rewriting the Just War Tradition: Just War in Classical Greek Political Thought and Practice", International Studies Quarterly, vol. 59, 1 (2015), p. 7.

${ }^{44}$ For a thoughtful discussion on this: Jenny Edkins, Trauma and the Memory of Politics (Cambridge, 2003), pp. 57-108.

45 Elshtain, "Just War and an Ethics of Responsibility", p. 142.
} 
the event? Is it a sacrifice to be redeemed, a legacy to be claimed, or a past to be shucked off and left behind? How Ireland addresses these issues will have a significant bearing on how it faces an increasingly uncertain future in what looks like an increasingly dangerous world. 46

Patrick Pearse and his comrades would of course have us believe that it is not merely a patrimony to be claimed, but a sacred charge to be honoured and fulfilled. If he and his comrades sacrificed their lives so that the generations that followed would know freedom and independence, theirs is a legacy that we must pick up and carry with us until it is realised (whatever that might mean). ${ }^{47}$ Others, like Geldof, and perhaps also the heirs of McDonald, would counsel that its memory should be kept alive-but as a warning.

It is, however, the words of Patti Smith that suggest the best way of approaching these issues. "Jesus died for someone's sins", she sang in Gloria, "but not mine." The idea to glean from this is that one need not negate or diminish the real sacrifices rendered by either Pearse and the men and women who fought alongside him in the Rising, or the innocents caught and killed in the crossfire, nor is one bound by them. While we might wish to honour their respective sacrifices, this does not mean that we are somehow obliged to carry their fight forward. Rather, it is for us to negotiate the enduring meaning of 1916 for ourselves. We should be free to study our past, and not be inhibited by the dead hand of history. This is the task of knowing and forgetting.

\footnotetext{
${ }^{46}$ A riff on the Stealers Wheels song doing the rounds in Ireland speaks to this: "Brexit to the left of me, Trump to the right of me, But here I am, Stuck in the middle with the EU."

${ }^{47}$ More could be said on the concept of sacrifice here. It is interesting to note that it plays across a number of different cases covered in this special issue, most notably Matt McDonald's study of the politics of ANZAC Day and Jessica Auchter's discussion of the Great War.
} 